\title{
VOLUNTARY ENVIRONMENTAL STANDARDS IN KEY RUSSIAN INDUSTRIES: A COMPARATIVE ANALYSIS
}

\author{
E. SHVARTS ${ }^{1}$, J. BUNINA ${ }^{2} \&$ A. KNIZHNIKOV 3 \\ ${ }^{1}$ Director of Conservation Policy, WWF Russia. \\ ${ }^{2}$ Postgraduate Student, University of Freiburg, Germany. \\ ${ }^{3}$ Head of the Programme for Environment Policy in the Power Generation and Mining Sectors, WWF Russia.
}

\begin{abstract}
This paper provides a comparative analysis of voluntary environmental standards in key Russian industries. Five Russian industries, namely the oil and gas, mining, power generation, forestry and financial sector, with a high economic and environmental impact were analysed in order to determine the degree of implementation of voluntary environmental standards. It was determined whether or not companies possess voluntary environmental standards and reporting, in the oil and gas, mining and electricity production industries, an ISO 14001 and/or sustainability (non-financial) reporting with confirmation by an independent third party in accordance with Global Reporting Initiative; in the forestry industry a Forest Stewardship Council certification; and in the financial sector the Equator Principles, United Nations Environmental Program Financial Initiative, Principles for Responsible Investments and Carbon Disclosure Project. The paper presents data and information on adherence to the above-mentioned standards by the main Russian companies by size in each sector. The research determined that the top performing industries are forestry and oil and gas, whereas the power generating industry and the financial sector show fairly low levels of implementation.
\end{abstract}

Keywords: International environmental standards, voluntary certification, sustainability reporting, Russia, oil and gas industry, mining, forestry, financial sector, FSC, ISO 14001, GRI.

\section{INTRODUCTION}

Russian business is nowadays rapidly becoming integrated with the world economy and, as such, global market trends do affect it. One of the main trends is the requirement for an objective confirmation that products meet certain ecological requirements. This is encouraged on a global political level in that actors, such as the European Union and the United Nations, promote it keenly. There is also a strong demand from middle-class consumers in OECD countries [1].

The environmental responsibility and friendliness of producers and the energy efficiency of goods will be among the main factors influencing global competition in the twenty-first century. This can already be seen in the incorporation of environmental responsibility indicators in investment attractiveness (notably in the Dow Jones Sustainability Indexes, which have existed since 1999), as well as in the development of voluntary environmental certifications, mechanisms for tracking the validity of products, etc. Environmental factors are also playing an ever-growing role in public procurement policy within the European Union, in many of the world's largest corporations and in investment policies of private and public pension funds as well as elsewhere. Not all countries, however, have shown a commitment to produce environmentally responsible products and to adopt the latest international environmental standards. Many companies in emerging and developing economies attempt to increase their profits and competitiveness through 'environmental dumping', i.e. lowering their costs whilst disregarding the environment. Some countries are changing their environment-related policies and requirements to favour these types of business strategies and national strategies for economic development. Such practice is common where environmental regulation by government is inadequate, as is the case with transition countries including Russia and many developing countries. As a rule, such practices are seen within the domestic markets of those countries where the middle class is relatively small and where consumers with low purchasing power tend to dominate. 
Russian companies have broad experience of working with different mandatory requirements and by-laws applied by various national agencies and their regional branches. Within the planned economy during the Soviet Union era, companies were obliged by the government to fulfill legal requirements of production processes and their products. Environmental and hygienic standards demanded high levels of compliance, but at times the various documents setting standards rose to almost 2,000 in number. This made it almost impossible to control, so creating many opportunities for corruption [2].

In recent Russian history, the government tried supporting a decrease in ecological standards ('ecological dumping') in order to attract investment from European countries in a form of 'competitive advantage' over Central and East European countries brought about by the requirement of new EU countries from Central and Eastern Europe not to have standards lower than EU directives. As a result of this policy, the independent governmental body, the State Committee for Environment Protection (Goskomekologia) that was controlling those ministries responsible for natural resource use, was disbanded in 2000 [3,4].

The decrease in environmental standards and the demolition of environmental governance in Russia was viewed to be a faster and easier alternative to improving the investment climate in Russia and lowering corruption levels $[2,3]$.

Nowadays in Russia, there are obligatory (state) and voluntary (mainly international) standards. In most cases, voluntary standards set additional or other (often higher) conditions or obligations. In cases where there is real public interest, they are much less susceptible to corruption, but are harder to achieve. Being granted an ecological voluntary certificate, however, gives a company a competitive advantage both within the ecologically aware OECD end-consumer markets and in attracting more long-term and cheaper financial resources [1,5].

There have been several analyses of environmental voluntary standards in Russia, but most of these focused on a single industry, usually the forestry industry, and on the subject of the successful implementation of Forest Stewardship Council (FSC) standards [6]. There were efforts to analyse three other industries, namely oil and gas, mining and electricity generation, in our previous research [1]. The current research builds on this previous experience, but also includes two other industries, namely forestry and the financial sector.

Purpose: The purpose of the research is to analyse the scale of implementation of voluntary environmental standards in several Russian industries (oil and gas, mining, power generation, forestry and finance) and to propose an explanation of the results obtained.

\subsection{Methodology}

The methodology used in our research was as follows:

1. Those industries within the Russian economy were chosen that have either high economic or environmental impact, but usually both. As an economic indicator, we chose the export earning potential of the industry as we consider the demand from external markets to be a key driver of voluntary certification and its implementation.

The oil and gas industry represented $71.1 \%$ of Russian exports in 2011, making it the country's biggest export sector [7]. During oil and gas extraction, however, the landscapes and biodiversity are affected dramatically. The mining industry is the second largest sector of the Russian economy in terms of exports contributing 6.1\% to total exports in 2011 [7].

Along with the oil and gas industry, mining affects the environment significantly moving as it does vast quantities of soil and overlay and reshaping landscapes. 
According to official statistics, the forestry industry represents $2.2 \%$ of total exports in 2011 [7]. It is worth mentioning that Russia has the largest area of forest in the World with more than 801 million hectares covering $49 \%$ of the country's land surface [8].

The power generation industry does not play an important role in Russian exports, but it is crucial for sustaining local economies and livelihoods. Though the economic share of energy exports is minor, the industry ranks at the top with regard to its contribution to greenhouse gas emissions compared with the other industries in Russia - the power generation sector contributes $46.1 \%$ of total emissions by sector [9].

The financial sector also does not contribute greatly to Russian exports, and financial institutions themselves do not directly affect the environment. The financial sector is responsible for providing the necessary investments for new projects. As such, therefore, it can either drive or discourage the development of environmentally friendly projects within the Russian Federation. The financial sector was selected for inclusion here in order to include a service industry in contrast to the other natural resource industries that were chosen.

Eventually, five industries were selected for analysis:
i. Oil and gas
ii. Mining
iii. Power generationForestry
iv. Financial sector

2. In selecting organisations to be analysed, we focused on the largest organisations in the industry based on national rankings and expert interviews (WWF). Selected companies represent the main players within the industry, so it should be possible to estimate the scale of certification implementation within the industry as a whole. It is worth mentioning that the market structure in each industry is very different. In the oil and gas industry, for example, there are approximately 15-20 real players in the whole industry, whereas in the banking sector there are more than 500. This is the reason why the number of companies chosen within each industry is different. The percentage of voluntary standards implementation in each industry provides a fairly accurate depiction of the industry, though we acknowledge some imperfection of sampling methodology due to lack of statistical data.

3. It was then determined whether or not selected companies from the five industries possess environmental voluntary standards and reporting. For the oil and gas, mining and electricity production industries these are ISO 14001 and sustainability reporting in accordance with requirements of the Global Reporting Initiative (GRI). For the forestry industry, it is FSC certification, whereas for the financial sector, the Equator Principles, the United Nations Environment Program Financial Initiative (UNEP FI), the Principles for Responsible Investments (PRI) and the Carbon Disclosure Project (CDP) apply.

ISO 14001 standards were chosen as being the most widespread environmental certification with associated statistics that are available.

The GRI was chosen because of its acceptance by the international community and because independent or third party audits and/or assurances could in some cases be a good alternative and/or counterbalance to state control and reporting in countries with high levels of corruption. Reports are produced using GRI guidelines and can then be assured by either the company itself (i.e. self-reported) or by a third party (i.e. publicly assured). A self-reported GRI is produced by the company itself and can then be forwarded for inclusion in the GRI international database. The problem with reports of this type is that they are not certified by a third party, so the information may not be fully reliable. This problem is solved using publicly assured GRI reports, usually 
formulated by an independent third party, frequently an auditing or certification company. The problem with this type of report, however, is that public assurance is an expensive procedure and not all companies are willing to spend money on it. Although we consider publicly assured GRI reports to be more credible, we take into account both types in acknowledging companies' actions towards more environmentally responsible practices. In our research, we consider a company to have a GRI report if the report was produced at least once since 2009 as not every organisation publishes a GRI report on a yearly basis.

FSC within the forest industry has been chosen as we consider it to be the model international ecological certification that focuses on end-user preferences to purchase legally obtained and sustainably produced timber.

For the financial sector Equator Principles, UNEP FI and PRI were chosen as these voluntary standards are the major accepted standards within the financial industry [10]. It was also taken into consideration whether or not a financial institution requires a disclosure of carbon emissions (CDP) from its customers.

To determine whether or not ecological standards are applied, either the companies' websites were accessed, or interviews were held with company representatives. Only production companies were analysed, as, due to the extensive and complex corporate structure that often exists, it would be next to impossible to track all the subsidiaries. The number of companies with self-reported GRI reports were compared with the number of companies with publicly assured GRI reports.

4. Finally, the percentage of organisations in each industry that have implemented environmental certification was calculated and an interpretation of the results is presented under Discussions and Conclusions section.

\subsection{Assumptions}

The following assumptions underlie this study:

1. Globalisation brings certification practices together.

It is impossible to deny that globalisation is taking place as a globalisation of peoples' ideas as well as in dimensions of a market. Nowadays, one of the most powerful concepts is the one of sustainable development or shifting towards a 'green' economy, i.e. the desire of people not to over-exploit resources and to care for nature. This leads to a more conscientious use of resources and to the notion that a customer must be aware of sustainability and environmentally and socially responsible use of products. In our research, the customer can be either an individual (end-consumers' preferences and behaviour), a government (government procurement policies), or a business corporation (corporate procurement policies). To satisfy a customer's demands, supplying companies must apply ecological voluntary certification.

Globalisation is also happening at the global market level. Countries are becoming more and more involved in trade with one another and markets are becoming more inter-dependent. Fastdeveloping means of communication (Internet, rapid transport, etc.) are turning the world into a 'global village' where information spreads very fast and all over. Even though distances are the same, aircraft and the Internet are making it easier to access any part of the 'shrinking' world. This in turn leads to the fact that practices are spreading faster and, in many cases, are being implemented worldwide.

2. As the world becomes a smaller place, multinational companies are attempting to establish similar corporate policies in every part of the Globe where they operate. The principle reason for this is that the corporate policies of these companies in, for example, Nigeria or Sakhalin Island 
(Russia) directly affect its reputation amongst shareholders in Canada, United Kingdom, The Netherlands or elsewhere.

3. The implementation of voluntary ecological certification has a positive effect on the environment. For example, ecological voluntary standards included in the International Social and Environmental Accreditation and Labeling (ISEAL) Alliance specifically focus on improvement impacts and unites major environmental standards, such as the FSC and the Marine Stewardship Council (MSC) etc. For example, with the implementation of MSC certification in 2006, it is believed that herring fisheries in the Northern sea increased by $15 \%$ [11]. Furthermore, numerous researchers have highlighted the positive impact of FSC on the state of forestry worldwide [12].

4. We strongly believe that effective environmental protection can be achieved only through a combination of mandatory legal requirements (laws and bylaws) and market-driven voluntary international ecological standards. Effective legal requirements do not allow corporations to use an environmental dumping strategy to obtain market advantage by minimizing expenditures for environmental protection purposes. At the same time market-driven voluntary eco standards allow companies to get market advantage for more environmentally responsible producers with higher environment and social standards. Mandatory standards can be more effective in those countries that do not have high levels of corruption. At the same time, market-driven environmental standards and initiatives are considered to be more effective in those countries with high corruption risks/levels because of the relative independence of third parties, such as independent certification bodies and auditors from government agencies.

A risk still exists, however, of bias on the part of independent certification bodies and auditors. Based on our experience in Russia, the 'big four' auditing companies can be influenced when assuring both financial and non-financial sustainability reports of leading state-owned oil and gas corporations. Large auditing companies receive much greater income from financial reports meaning that sustainability reports are often dispensed as a 'reward' for choosing their services. Small auditing companies are sometimes also influenced in the same way. Nevertheless, independent third parties are an effective instrument in combating corruption and political bias within emerging markets in countries such as Russia because certification bodies and auditors put their finances and reputation at risk if their actions are seen to be biased. For example, in 2000, Greenpeace Russia appealed against Institut für Marktökologie (IMO), the oldest FSC certification body (accredited for FSC since 1 July, 1998) for issuing three certificates for a forest lease for Dammers, (part of the German Holz-Dammers-Mojers Group). Even though only one FSC certificate was subsequently recalled, IMO, one of the first and most well-known international bodies for certification and quality assurance of sustainable products and with operations in more than 90 countries, had to leave Russia and so lose the second largest market for FSC certification.

In the developing countries and in rapidly growing economies such as in Russia, national certifications are not wholly trusted by middle class consumers, companies and investors in OECD and other international bodies. There are two reasons why national certifications are not trusted. The first is that there are risks of lower local standards being applied compared with international voluntary systems and the second is that corruption andlor politically driven implementation takes place. For example, the Russian Union of Industrials and Entrepreneurs officially estimates that the annual 'informal business expenditures' for acquiring permission to indulge in air and water pollution, waste utilisation, standards and other legal documents is approximately 100 billion rubles (EUR 2.4 billion) [13]. For this reason, we opt for a market-driven voluntary ecological certification as the chances of experiencing unbiased actions by auditing companies (driven by the fear of reputational risks) is much higher than the chance of unbiased actions from corrupted government officials. 


\section{RESULTS}

2.1 Overview of Russian ecological voluntary certification practices on a global scale

According to the ISO Survey 2010, Russia stood in 18th place according to the number of ISO 14001 certificates obtained. In 2012, however, Russia was ranked 34th. The reason for this drop in ranking was that some other countries experienced a significant increase in the number of ISO 14001 certificates, whilst the number in Russia did not just stagnate, but fell by 863 (Table 1). This can be explained by the fact that recently Russian authorities have started issuing ISO 14001-2007, this certificated equals to ISO 14001-2004. Thus, as many organisations have 'local' ISO 14001 certificate - they cease to inform International Standard Organisation about the amount of issues certificates. Based on the evidence of Russian certification bodies there is no dramatic decrease of ISO issue. This is the reason why it is difficult to give an assessment of the major decline in numbers of ISO 14001 certificates in Russia after 2010.

\subsection{Oil and gas industry}

Russia is the second largest producer of natural gas and the third largest producer of liquid fuels in the world [14]. The oil and gas industry contributes $71.1 \%$ to Russian exports [7] and is nowadays the backbone of the Russian economy. High oil prices during the 2000s were the key contributing factor to the economic development of the country at the time. There is one leading state-owned gas producer, Gazprom, which accounts for approximately $70 \%$ of total gas production in Russia and

Table 1: The number of ISO 14001 certificates by country.

\begin{tabular}{|c|c|c|c|c|c|c|c|c|}
\hline Rank & Year & 2006 & 2007 & 2008 & 2009 & 2010 & 2011 & 2012 \\
\hline 1 & China & 18,842 & 30,489 & 39,195 & 55,316 & 69,784 & 81,993 & 91,590 \\
\hline 2 & Japan & 22,593 & 27,955 & 35,573 & 39,556 & 34,852 & 30,397 & 27,774 \\
\hline 3 & Italy & 9,825 & 12,057 & 12,922 & 14,542 & 17,064 & 17,418 & 19,705 \\
\hline 4 & Spain & 11,125 & 13,852 & 16,443 & 16,527 & 18,347 & 16,341 & 19,470 \\
\hline 5 & United Kingdom & 6,070 & 7,323 & 9,455 & 10,912 & 14,346 & 15,231 & 15,884 \\
\hline 6 & Korea, Republic of & 5,893 & 6,392 & 7,133 & 7,843 & 9,681 & 11,124 & 11,479 \\
\hline 7 & Romania & 1,454 & 2,269 & 3,884 & 6,863 & 7,418 & 7,394 & 8,633 \\
\hline 8 & France & 3,047 & 3,476 & 3,482 & 4,678 & 5,251 & 7,771 & 7,975 \\
\hline 9 & Germany & 5,415 & 4,877 & 5,709 & 5,865 & 6,001 & 6,254 & 7,034 \\
\hline 10 & USA & 5,585 & 5,462 & 4,974 & 5,225 & 4,407 & 4,957 & 5,699 \\
\hline 32 & Portugal & 564 & 456 & 534 & 632 & 838 & 836 & 1,184 \\
\hline 33 & Mexico & 409 & 739 & 832 & 870 & 808 & 858 & 1,096 \\
\hline 34 & Russian Federation & 223 & 267 & 720 & 1,503 & 1,953 & 1,093 & 1,090 \\
\hline 35 & Austria & 553 & 697 & 837 & 919 & 1,182 & 963 & 1,084 \\
\hline 36 & Chile & 375 & 492 & 686 & 576 & 714 & 617 & 1,080 \\
\hline 37 & Hong Kong, China & 509 & 522 & 739 & 845 & 1,012 & 985 & 1,060 \\
\hline
\end{tabular}


approximately 11 large oil extracting companies in the country. Five of the 11 companies analysed are among the top 10 Russian companies according to revenue generated [15] with all 11 of them being included in the top 40. Russian oil and gas companies are actively involved in international trade with, as has already been mentioned, $70 \%$ of the extracted oil being exported. Furthermore, $60 \%$ and $90 \%$, respectively, of Russian oil and gas is exported to the European Union, thus making this industry very dependent on European partners [16].

It is worth mentioning that a number of companies included in Table 2 are owners of some of the other companies listed in the same table (e.g. Gazprom - Gazpromneft; Gazpromneft and Rosneft Slavneft). All the companies in the table are viewed as being independent as each retains its own internal policies as well as being free to formulate corporate social responsibility policy. In addition, the companies are not operationally subordinate to their shareholders.

All of the analysed companies have ISO 14001 and $73 \%$ of them have self-reported GRI. It is also worth mentioning that $45 \%$ of the companies have publicly assured reports. These are the highest figures for all the industries analysed. This can be explained by the fact that a significant portion of the companies have a major presence on European (Gazprom and Lukoil and to a lesser degree Rosneft) and North American (Lukoil) markets and are pushing to comply with international environmental standards and requirements of intergovernmental and private financial institutions from OECD countries (Table 2).

\subsection{Mining industry}

Russian mining companies are usually privately owned, five of which generate two-thirds of the industry's revenue. Severstal, Evraz and Norilsky Nikel are the largest players in the field. There are many other companies in the industry. Even though they receive less revenue than the five big players, they do exert a tremendous pressure on the environment. For the analysis and based on a report on the mining industry in Russia [17], 17 large companies within the industry were chosen.

Table 2: ISO 14001 certification and sustainability reporting in the oil and gas industry.

\begin{tabular}{|c|c|c|c|c|}
\hline No. & Company & $\begin{array}{c}\text { ISO } \\
14001\end{array}$ & $\begin{array}{c}\text { SF+GRI self } \\
\text { reported }\end{array}$ & $\begin{array}{l}\text { SF+GRI } \\
\text { publicly } \\
\text { assured }\end{array}$ \\
\hline 1 & Gazprom & Yes & Yes & No \\
\hline 2 & Lukoil & Yes & Yes & No \\
\hline 3 & Rosneft & Yes & Yes & Yes \\
\hline 4 & TNK BP & Yes & Yes & Yes \\
\hline 5 & Surgutneftegaz & Yes & No & No \\
\hline 6 & Tatneft & Yes & Yes & Yes \\
\hline 7 & Gazpromneft & Yes & Yes & No \\
\hline 8 & Novatek & Yes & Yes & Yes \\
\hline 9 & Slavneft & Yes & No & No \\
\hline 10 & Rusneft & Yes & No & No \\
\hline \multirow[t]{2}{*}{11} & Bashneft & Yes & Yes & Yes \\
\hline & Total percentage & 100 & 73 & 45 \\
\hline
\end{tabular}

SF, sustainability (non-financial) reporting; GRI, global reporting initiative. 
Ninety-four percent of the analysed companies have acquired ISO 14001 standard. Of these, $65 \%$ have a sustainability report done in accordance with GRI principles. Only $16 \%$ of the companies, however, went through the GRI public assurance procedure. As can be seen, the difference between self-reported GRI $(65 \%)$ and publicly assured GRI (16\%) is markedly greater than is the case with oil and gas companies. The assumption is that mining companies use GRI sustainability reporting more as a marketing tool rather than for other reasons (e.g. minimisation of environment risks or responsibility towards the environment) and that Russian mining companies have less of a presence on the more environmentally aware internal markets in OECD countries when compared with Russian oil and gas companies (Table 3).

\subsection{Power-generation industry}

Reform has taken place in the power-generation industry in Russia. The goal of the reform was to switch Russian power generation from a government monopoly to a market-based industry. Before 2008, most power-generating facilities were owned by a government company, RAO EUS. After 2008, RAO EUS was split up. Currently, there are two types of electricity-generating companies: OGK and TGK. OGKs are federal-scale wholesale electricity-generating companies that produce electricity from coal and gas. There are five OGKs in Russia. TGKs are territorial electricity-generating companies that are smaller scale companies producing not only electricity but also heat for towns and villages. There are 14 TGKs in Russia.

Table 3: ISO 14001 certification and sustainability reporting in the mining industry.

\begin{tabular}{lllll}
\hline & & & & SR+GRI \\
No. & Company & $\begin{array}{l}\text { ISO } \\
\text { SR+GRI }\end{array}$ & $\begin{array}{l}\text { Sublicly } \\
\text { self-reported } \\
\text { assured }\end{array}$ \\
\hline 1 & Severstal & Yes & Yes & Yes \\
2 & Evraz Group & Yes & No & No \\
3 & Norilsky Nikel & Yes & Yes & No \\
4 & UC Rusal & Yes & Yes & No \\
5 & EuroChem & Yes & Yes & No \\
6 & Metalloinvest & Yes & Yes & Yes \\
7 & Magnitogorsk Iron and Steel Works & Yes & Yes & No \\
8 & Novolipetsk Steel & Yes & Yes & No \\
9 & Polymetal International & Yes & Yes & No \\
10 & Polus Gold & Yes & Yes & Yes \\
11 & Uralkali & Yes & Yes & No \\
12 & Petropavlovsk plc & No & Yes & No \\
13 & Chelyabinsk Zink Plant & Yes & No & No \\
14 & Ferrexpo plc & Yes & No & No \\
15 & Koks group & Yes & No & No \\
16 & Atompredmet Gold & Yes & No & No \\
17 & TMK & Yes & No & No \\
& Total percentage & $\mathbf{9 4}$ & $\mathbf{6 5}$ & $\mathbf{1 6}$ \\
\hline
\end{tabular}


Among the analysed companies, only 35\% have ISO 14001 and 10\% have self-reported GRI. Only one company from the analysed list (i.e. 5\% of the total) went through a public assurance procedure. This can be explained by the fact that electricity-generating companies focus on the local market and the internal market in China, both markets displaying low levels of environment awareness and sensitivity (Table 4).

\subsection{Forestry industry}

All Russian forests are government owned, but a company can lease a forest for up to 49 years. Approximately 20\% of forests in Russia are currently leased $-18.6 \%$ in 2012 and 19.5\% in 2013.

An FSC certification is the most globally acknowledged scheme for sustainable forest management. FSC issues two different types of certificate: FSC Forest Management and FSC Chain of Custody. An FSC Forest Management certificates certifies that a forested area is sustainably managed, whereas an FSC Chain of Custody certificate is issued to a production company to certify that it uses only sustainable timber [18].

An FSC Forest Management certification is extremely successful in Russia. Currently, Russia has the second largest forest certified area after Canada (Fig. 1). The FSC Forest Management scheme

Table 4: ISO 14001 certification and sustainability reporting in the power-generation industry.

\begin{tabular}{lllll}
\hline & & & & ISO \\
No. & Company & $\begin{array}{l}\text { SF+GRI } \\
\text { self-reported }\end{array}$ & $\begin{array}{l}\text { SFblicly } \\
\text { assured }\end{array}$ \\
\hline 1 & OGK-2 & Yes & Yes & No \\
2 & RusHydro & Yes & Yes & Yes \\
3 & TGK-3 Mosenergo & Yes & No & No \\
4 & OGK-5 Enel & Yes & No & No \\
5 & TGK-2 & Yes & No & No \\
6 & TGK-10 & Yes & No & No \\
7 & TGK-11 & Yes & No & No \\
8 & OGK-1 & No & No & No \\
9 & OGK-3 & No & No & No \\
10 & OGK-4 (E.On) & No & No & No \\
11 & TGK-1 & No & No & No \\
12 & TGK-4 Quadra & No & No & No \\
13 & TGK-5 & No & No & No \\
14 & TGK-6 & No & No & No \\
15 & TGK-7 Volzskaya & No & No & No \\
16 & TGK-8 Lukoil Energo & No & No & No \\
17 & TGK-9 & No & No & No \\
18 & TGK-12 Kuzbas Energo & No & No & No \\
19 & TGK-13 Eniseyskaya & No & No & No \\
20 & TGK-14 & No & No & No \\
& Total percentage & $\mathbf{3 5}$ & $\mathbf{1 0}$ & $\mathbf{5}$ \\
\hline
\end{tabular}




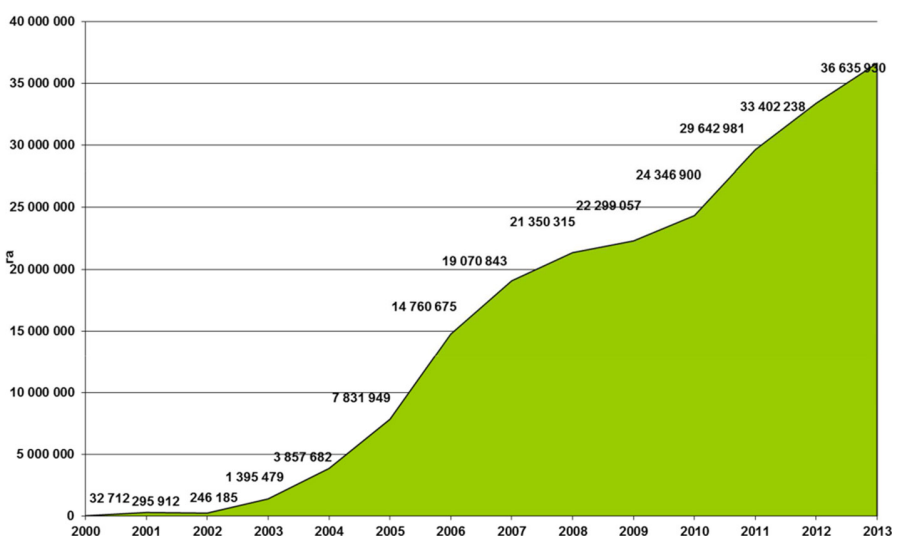

Figure 1: The growth of forest area under FSC Forest Management-certification (by data from www.fsr.ru at the end of 2013).

was introduced in the late-1990s. The scheme experienced rapid growth in Russia after 2003 and by 2013, more than 36,000,000 ha of certified forest existed (Fig. 1).

With respect to FSC Chain of Custody, Russia is also very successful. Although slightly less established than FSC Forest Management, it has been developing at a higher rate in recent years. The biggest consumers of FSC-certified products are pulp-mills plants, firstly, due to an ability to process more timber, and secondly due to a significant share of FSC-certified timber in use. The important consumers are also 'do it yourself' or DIY companies, such as IKEA, OBI, etc.

The top five Russian forestry companies generate roughly $50 \%$ of the industry's total revenue [19]. The forest industry as a whole, however, brings in only $1-1.5 \%$ of the country's budget. For our analyses, we selected the 19 largest companies based on the available statistics and consultations with the WWF-Russia Forestry Programme.

Of the analysed forestry companies, $89 \%$ possess FSC Chain of Custody, whereas 53\% have FSC Forest Management (Table 5). The comparatively lower figure for FSC Forest Management can be explained by the fact that not all companies in the list lease forestry areas. They instead become timber processors by purchasing timber from other companies.

\subsection{Financial sector}

The objectives of responsible financial principles are to ensure that investments are made in environmentally and socially friendly projects. Responsible finance instruments began emerging in the 1980s and continue to evolve and improve and are now attracting more countries and major banks. Among others, there is the UNEP FI and the Equator Principles. Under UNEP FI, a bank is signing a statement that says. 'By signing up to the Statement, financial institutions openly recognise the role of the financial services sector in making our economy and lifestyles sustainable and commit to the integration of environmental and social considerations into all aspects of their operations' [20]. The underlying idea of the Equator Principles is similar: 'Equator Principles Financial Institution commit to implementing the Equator Principles in their internal environmental and social policies, procedures and standards for financing projects and will not provide Project Finance or ProjectRelated Corporate Loans to projects where the client will not, or is unable to, comply with the Equator Principles' [21]. 
Table 5: FSC certification in the forestry industry.

\begin{tabular}{llll}
\hline & & FSC Chain of & FSC Forest \\
No. & Company & Custody & Management \\
\hline 1 & Ilim Group & Yes & Yes \\
2 & OJSC 'Mondi Business Paper Syktyvkar' & Yes & Yes \\
3 & Ilim Timber & Yes & No \\
4 & Investlesprom & Yes & Yes \\
5 & International Paper & Yes & Yes \\
6 & Sveza & Yes & Yes \\
7 & Arkhangelsky pulp mill holding & Yes & No \\
8 & Kondopoga & Yes & No \\
9 & Titan group & Yes & Yes \\
10 & Volga & Yes & No \\
11 & Solikamskbumprom & Yes & Yes \\
12 & Novoenisejsky Lpk & Yes & No \\
13 & Knauf St. Petersburg & No & No \\
14 & PCBK Group - Perm & No & No \\
15 & Continental Management & Yes & Yes \\
16 & Terneyles & Yes & Yes \\
17 & Lesosibisky LDK & Yes & No \\
18 & Vologodskie lesopromyshlenniki & Yes & Yes \\
19 & RFP Group & Yes & No \\
& Total percentage & $\mathbf{8 9}$ & $\mathbf{5 3}$ \\
\hline
\end{tabular}

The banking sector is enlarging its share of Russia's GDP. However, the devolvement of the banking sector began only 20 years ago and it will therefore take time until the sector is fully developed. For our research purposes, the 14 largest banks [22] were chosen, as well as - the Russian Development Corporation of Russia, Vnesheconombank.

Only one out of the 15 analysed institutions declare compliance with any given set of sustainable finance principles. Vnesheconombank, which in 2013 became a member of the UNEP FI, represents $6.7 \%$ of the industry (Table 6). Although Otkritie Bank (ranked No. 9 by size in 2013) was the only bank in Russia to have signed the Equator Principles. A year after re-orientation of the bank to focus on small- and medium-sized businesses due to a process of sharing responsibilities with other financial institutions from the same business group (Nomos Bank), membership of Otkritie Bank in the Equator Principles group was not re-confirmed. It is worth mentioning that, in the field of financial principles implementation, Russia is not only behind its OECD partners, but also behind Brazil, Russia, India, China, South Africa (BRICS) country partners (Table 6).

\section{DISCUSSIONS AND CONCLUSIONS}

The results of our research are summarised in Table 7.

Within the forestry industry, FSC certification was examined. Eighty-nine percent of analysed organisations possess FSC Chain of Custody certificates and 53\% have FSC Forest Management certificates. This clearly reflects the high environmental awareness of the international forest products market and the global environmentally aware procurement policies of the principal international 
Table 6: Responsibility mechanisms in the banking industry.

\begin{tabular}{lll}
\hline No. & Bank & Responsibility mechanism \\
\hline 1 & Vnesheconombank & UNEP Financial Initiative (2013) \\
2 & Sberbank & No \\
3 & VTB & No \\
4 & Gazprombank & No \\
5 & Russian Agricultural Bank & No \\
6 & VTB24 & No \\
7 & Bank of Moscow & No \\
8 & Alfa Bank & No \\
9 & Bank «Otkritie» & No \\
10 & Rosbank & No \\
11 & Uralsib & No \\
12 & Nomosbank & No \\
13 & Petrokommerz & No \\
14 & Nomos Bank/Financial Corporation 'Otkritie' & No \\
15 & Promsvyazbank & $\mathbf{6 . 7}$ \\
& Total &
\end{tabular}

${ }^{a}$ Compliance with the Equator Principles was announced in 2013, but was not re-confirmed after bank restructuring.

Table 7: Environmental voluntary standards in five key Russian industries.

\begin{tabular}{|c|c|c|c|c|c|}
\hline No. & Industry & $\begin{array}{l}\text { Analysed } \\
\text { environmental } \\
\text { mechanism }\end{array}$ & $\begin{array}{l}\text { Number of } \\
\text { companies } \\
\text { analysed }\end{array}$ & $\begin{array}{l}\text { Number of } \\
\text { companies } \\
\text { which have } \\
\text { implemented } \\
\text { environmental } \\
\text { voluntary } \\
\text { standards }\end{array}$ & $\begin{array}{l}\text { Share }(\%) \text { of } \\
\text { companies with } \\
\text { implemented } \\
\text { environmental } \\
\text { voluntary standards } \\
\text { out of analysed } \\
\text { companies }\end{array}$ \\
\hline \multirow[t]{2}{*}{1} & \multirow[t]{2}{*}{ Forestry } & $\begin{array}{l}\text { FSC chain of } \\
\text { custody }\end{array}$ & 19 & 17 & 89 \\
\hline & & $\begin{array}{l}\text { FSC forest } \\
\text { management }\end{array}$ & & 9 & 53 \\
\hline \multirow[t]{2}{*}{2} & \multirow[t]{2}{*}{ Oil and gas } & ISO 14001 & 11 & 11 & 100 \\
\hline & & SR+GRI & & 5 & 45 \\
\hline \multirow[t]{2}{*}{3} & \multirow[t]{2}{*}{ Mining } & ISO 14001 & 17 & 16 & 94 \\
\hline & & SR+GRI & & 3 & 16 \\
\hline \multirow[t]{2}{*}{4} & \multirow{2}{*}{$\begin{array}{l}\text { Electricity } \\
\text { production }\end{array}$} & ISO 14001 & 20 & 7 & 35 \\
\hline & & SR+GRI & & 1 & 5 \\
\hline 5 & Financial sector & UNEP FI & 15 & 1 & 6.7 \\
\hline
\end{tabular}

SR+GRI - publicly assured SF in accordance with GRI requirements. 
companies working in the forestry sector which are oriented towards FSC-certified commodities within the market and which generate high levels of competition between timber, pulp and paper producers. Clearly, the forestry sector is now one of the most environmentally responsible sectors in the Russian economy.

The industries for which ISO 14001 and sustainability reporting with GRI were analysed (oil and gas, mining, electricity generation) showed that the oil and gas industry has the widest scale of voluntary standards implementation (100\% ISO 14001 and $45 \%$ of publicly assured sustainability (non-financial) reporting (SF) out of the analysed organisations). The power-generating industry, however, has a fairly low implementation level (35\% ISO 14001 and 5\% publicly assured SF out of the analysed organisations).

Only one bank, Russian Development Bank, has a responsibility mechanism in the form of the UNEP FI. This result equates to only $7 \%$ of the analysed financial institutions and this is the lowest result from all analysed industries.

A clear correlation can be seen between voluntary environmental standards implementation and the inclusion of the industry in global commerce, but especially with OECD countries. The relatively positive results of the oil and gas industry can be explained by competition for long-term and cheaper financial resources and with the high interconnection of the industry with EU partners. Mining and power-generation industries are less ecologically aware, as both of the industries have fewer consumers in the European Union and North America, as well as less pressure from international financial institutions. It is important to mention that ISO 14001 has much more of a technical role and does not attract the same attention, demand and support from the public and consumers when compared with FSC and publicly assured SF in accordance with GRI standards.

Voluntary environmental standards are the least spread in the Russian financial sector. This can be explained by the fact that financial intermediaries do not perceive direct and indirect social and environmental risks as significant for their financial stability. Environmental, Social and Governance (ESG) issues in most cases are considered for immediate operations and initiatives (saving power in offices, collecting garbage, social programmes for staff, etc.) or under charity programmes. Another explanation is that international environmentally and socially responsible investors such as private pension funds and shareholders from OECD countries still have a much lower influence on the Russian financial sector despite the potential to introduce relevant changes in this sector. Russian financial institutions do not deal with middle class final consumers and shareholders compared to the other analysed industries. EBRD is one of the key drivers of responsible finance through the network of partner-banks, which have to follow EBRD requirements, still these requirements most likely are not sustainable in the long-term perspective for the reasons mentioned above - responsible finance is not a business model for Russian financial intermediaries and create additional cost, rather than competitive advantage.

The dynamics of environmental voluntary standards implementation are expected to remain mostly the same as the Russian economy continues to integrate into the world's economy. Even taking into account the current political estrangement of the Russian Federation, reliable international standards in the environmental field could become the driver of mutual understanding in the political arena. At the same time, Russia-China economic cooperation is growing and this could be one of the reasons for the decline in the environmental standards and practices of Russian business corporations, particularly those that are state owned, and especially for in a short-term perspective.

Voluntary ecological mechanisms (certifications, non-financial reporting, etc.) based on international standards and confirmed by independent third parties could effectively enhance state mandatory environmental regulation and control in growing economies with low resistance to corruption and/or an absence of relevant capacities in governing state bodies. Voluntary ecological 
mechanisms can prevent or minimise negative effects from 'environment dumping' strategies of economic development by countries and corporations. Environmental voluntary standards can improve existing weaknesses of government environmental legislation and quality of environment management institutions on condition that public policy becomes more democratic and shifts towards more environmental sound policies.

\section{ACKNOWLEDGEMENTS}

We express our appreciation to Dr. Sergey Dayman, Cleantech and Sustainability Services Manager from Ernst \& Young (CIS) B.V. branch in Moscow for criticism, advice and recommendations on the first draft of this article. We also warmly thank Mr. Alexander Voropaev, Head of the Global Forest and Trade Network (GFTN), Russia, for his help and consultations on forestry and FSC issues. Finally, we would like to thank Jennie Sutton and Philip Johnson for helping us with the text proofreading.

\section{REFERENCES}

[1] Shvarts, E., Kniznikov, A. \& Bunina, J., Russian business and sustainable development: implementation of international standards in environmental risk management (Chapter 8). UNDP National Human Development Report for the Russian Federation, ed. S.N. Bobylev, UNDP: Moscow, pp. 143-162, 2013. doi: http://dx.doi.org/10.2139/ssrn.2328178

[2] World Bank, Russia Environmental Management System: Directions for Modernization, Public expenditure review (PER), World Bank: Washington, DC, available at http://documents. worldbank.org/curated/en/2009/05/11210086/russia-environmental-management-system-directions-modernization, 2009.

[3] Larin, V., Mnatsakanian, R., Chestin, I. \& Shvarts E., Okhrana Prirody Rossii: Ot Gorbacheva do Putina. (Nature Protection in Russia: From Gorbatchev to Putin), World Wide Fund for Nature (WWF): Moscow, 2003.

[4] Henry, L.A. \& Douhovnikoff, V., Environmental issues in Russia. Annual Review of Environment and Resources, 33, pp. 437-460, 2008. doi: http://dx.doi.org/10.1146/annurev.energy.33.051007.082437

[5] Shvarts, E. \& Gerasimchuk, I., Environmental policy and the international competitiveness of the Russian economy. Environmental Finance and Responsible Business in Russia: Legal and Practical Trends, eds. F.M. Mucklow \& Dr. W.Th. Douma, T.M.C., Asser Press: The Hague, pp. 121-131, 2010. doi: http://dx.doi.org/10.1007/978-90-6704-529-2_9

[6] Tulaeva, S., Transformasiya korporativnoy social noi otvetstvennosti predpriyatii lesnogo sektora pod vliyaniiem global'nykh protsessov (Translation: Transformation of corporate social responsibility in the forestry sector under the influence of the global processes). Zhurnal Sottsiologii i Sotsialnoi Antropologii (Translation: Journal of the Sociology and social Anthropology), 10, pp. 112-126, 2007.

[7] Federal State Statistic Service, http://www.gks.ru

[8] UN data - Country profile Russian Federation, https://data.un.org/CountryProfile. aspx?crName=Russian\%20Federation

[9] Climate Policy and Emissions Data Sheet: Russia, Yale, available at http://envirocenter.yale. edu/uploads/pdf/Russia_Climate_Policy_Data_Sheet.pdf, 2005.

[10] Gerasimchuk, I., Ilymzinova, K. \& Schorn, A. (eds), Pure Profit for Russia: Benefits of Responsible Finance. WWF's Trade and Investment Program Report, WWF: Moscow, 2010. doi: http://dx.doi.org/10.2139/ssrn.1592859

[11] Global Impacts Report, Marine Stewardship Council, available at http://www.msc.org/documents/environmental-benefits/global-impacts/msc-global-impacts-report-2013, 2013. 
[12] Romero, C., Putz, F., Guariguata, M., Sills, E., Carutti, P. \& Lescuyer, G., An overview of current knowledge about the impacts of forest management certification: a proposed framework for its evaluation. CIFOR, Bogor: Indonesia, 2013. doi: http://dx.doi.org/10.17528/cifor/004188

[13] Netreba, P., Na prirodu s chistoi sovestyu (Translation: Having a good conscious for nature). Kommersant, 104, p. 6, 2013.

[14] US Energy Information Administration, available at http://www.eia.gov/

[15] 2012 Ranking Expert - 400, Expert Russia, available at http://expert.ru/dossier/rating/expert-400/, 2013.

[16] Paillard, , Russia and Europe's mutual energy dependence. Journal of International Affairs, 63, pp. 65-84, 2010.

[17] Metalurgiceskaya i gornodobivaushaya promishlennost` v Rossii i SNG (Translation: Mining industry in Russia and CSR) Pricewaterhouse Coopers (PwC), available at http://www.pwc.kz/ en_KZ/kz/publications/Metals_Mining_Russia_the_CIS_rus_2011_fin.pdf, 2011.

[18] Tysiachniouk, M., Transnational Governance through Private Authority - The Case of Forest Stewardship Council Certification in Russia, Vol. 7, Wageningen Academic Publishers: The Netherlands, 2013. doi: http://dx.doi.org/10.3920/978-90-8686-772-1

[19] Lesprom, available at http://www.lesindustry.ru/top/

[20] UNEP Finance Initiative, available at http://www.unepfi.org/

[21] Equator Principles, available at http://www.equator-principles.com/

[22] RBC Banks Rating, available at http://rating.rbc.ru/category.shtml?method/925574 
